\title{
Producción de espacio en la ciudad de Lima: la estética de los im/propio en la poesía de Domingo de Ramos.
}

\section{Production of Space in the City of Lima: The Im/Proper Aesthetics in Domingo de Ramos's Poetry.}

\section{Resumen}

La poesía de Domingo de Ramos ha sido interpretada como la voz del migrante, aquello que está por ende asociado a lo rural, no español, no literario. Cambio el enfoque e indago en la crítica literaria que identifica la poesía de de Ramos con su biografía, interrogando también otros discursos que trataron los pueblos jóvenes como espacios carentes de arquitectura, definidos por el paisaje y la naturaleza. Llamo la atención hacia estrategias conceptuales interdisciplinarias que buscan mantener el espacio de los pueblos jóvenes completamente diferenciado, externo e independiente a la ciudad de Lima.

Palabras claves

Poesía, Literatura, Espacio Urbano, migración, arquitectura, Violencia.

\begin{abstract}
Domingo de Ramos's poetry has been primarily interpreted as the voice of the migrant, associated with the rural, non-Spanish, non-literary. I change the focus and inquire into the literary criticism that identifies de Ramos's poetry with his biography, while also looking into other discourses that treated the shantytowns as a space devoid of architecture, defined by nature and landscape. I draw attention to interdisciplinary conceptual strategies that seek to maintain the shantytown as a completely differentiated site, external and independent of the city of Lima.
\end{abstract}

Keywords 
CATEDRAl Tomada: Revista de crítica literaria latinoamericana / Journal of Latin American Literary Criticism Producción de espacio en la ciudad de Lima: la estética de los im/propio en la poesía de Domingo de Ramos.

Siempre me han querido etiquetar en el discurso subte, social, y soy más que eso, soy más que un marginal.

Domingo de Ramos ${ }^{1}$

El poemario Arquitectura del espanto de Domingo de Ramos aparece en 1988 publicado por la pequeña editorial Asalto al Cielo dirigida por Róger Santiváñez y José Antonio Mazzotti. La escritura de los poemas se remonta a 1982 y diferentes versiones de los mismos aparecen publicadas en fanzines, revistas y antologías de la época ${ }^{2}$. El poemario tiene la siguiente estructura: I. Soledad López, II. Arquitectura del espanto y III. N.N. Estas secciones dibujan un recorrido que parte de la exploración de una subjetividad amenazada por la soledad pasando por una experimentación espacial de la ciudad para terminar en un reflexión corporal y una mirada sobre los procedimientos biopolíticos y las consecuencias sociales del conflicto armado.

Cuando de Ramos empieza a escribir estos poemas es miembro del grupo $K l o a k a^{3}$, una agrupación de poetas jóvenes de las universidades Católica y San Marcos, cuyo líder efectivo es Santiváñez quien recuerda la entrada al colectivo de de Ramos así: "Después de unos años Mariela Dreyfus me habló de un estudiante de Sociología que escribía poemas. Se trataba de Domingo. Justamente en Kloaka buscábamos a alguien proveniente de barrios marginales y él llegaba

\footnotetext{
${ }^{1}$ Entrevista realizada por la poeta Cecilia Podestá aparecida en el semanario Siete.

${ }^{2}$ Algunos poemas fueron publicados en Haraui editada por Francisco Carrillo de la Universidad San Marcos y en la plaqueta de Kloaka internacional en 1986. Otros son reproducidos en la antología de 1987 La última cena. Poesía peruana actual.

${ }^{3}$ Kloaka es fundado por los poetas Mariela Dreyfus y Roger Santiváñez, en setiembre de 1982. Tiene también en sus filas a Guillermo Gutiérrez, Edián Novoa (narrativa), Julio Heredia, Domingo de Ramos, Mary Soto, José Alberto Velarde y Enrique Polanco (pintura). Dalmacia Ruiz Rosas y José Antonio Mazzotti se dan a conocer luego como "aliados principales" en una segunda etapa que empieza en los primeros meses del año 84 tras la separación y expulsión de cuatro miembros (Dreyfus, Soto, Hidalgo y Gutiérrez).
} 
de los conos: era la voz del proletariado" (cursivas mías, Yrigoyen y Rotondo, 218).

De tal modo, de Ramos viene a llenar un cálculo literario que se fija en lo biográfico y lo social, que parte de sus compañeros del colectivo poético, pero que pronto se desplaza a la crítica literaria y cultural, influenciando su recepción desde la década del ochenta hasta la actualidad. En ese sentido, me interesa como poesía y autor en tanto asume y rechaza la autobiografía. Se identifica como marginal, al tiempo que contradice y cuestiona esa posición.

Kloaka utiliza el shock como procedimiento discursivo a partir de sus manifiestos y comunicados grupales. El colectivo poético toma como mandato comunitario constituirse en espejo de la coyuntura: "Nuestro rol es escribir, crear textos que puedan expresar que lo que está sucediendo en el Perú, es una situación cloaca, el Perú es una cloaca" (Zevallos $M K$ 96). La pobreza, el racismo, la migración y la violencia incrementada por el conflicto armado interno (19802000) son las condiciones sociales frente a las cuales el colectivo se pronuncia. Desde esta perspectiva de época y a partir del dato autobiográfico se lee a de Ramos quien migra siendo niño al arenal de San Juan de Miraflores. En tanto los pueblos jóvenes son entendidos como desborde urbano ${ }^{5}$ y periferia, este rasgo de marginalidad topológica de uno de los miembros se asume como coherente con la posición marginal que los Kloaka buscan ocupar y ocupan dentro del campo

\footnotetext{
${ }^{4}$ Proletariado sea tal vez una licencia poética de de Ramos. Los científicos sociales de la época entre los que destacan Degregori, Blondet, Lynch, Golte cuentan que poco menos de un tercio de los habitantes de los pueblos jóvenes son obreros. Justamente, la economía que se produce a partir de la migración es la denominada informal, caracterizada por el comercio, en su mayoría ambulatorio, y por la constitución de empresas y servicios que no actúan dentro del reglamento: no pagan impuestos o seguros médicos a sus trabajadores, no tramitan permisos, etc.

${ }^{5}$ Hay dos grandes migraciones a Lima de peruanos de las provincias del interior en el siglo XX. La primera se da a inicios de la década del cuarenta y la segunda empieza en la década del setenta haciéndose más evidente en la siguiente (Degregori Conquistadores 25). El conflicto armado agudiza la migración interna y los migrantes se colocan al centro de un fenómeno urbano que es estudiado por las ciencias sociales. El antropólogo ayacuchano Matos Mar acuña la frase "desborde popular" para caracterizar estas migraciones que se perciben como fenómenos naturales que desbordan los límites de una ciudad bien contenida.
} 
CATEDRAL Tomada: Revista de crítica literaria latinoamericana / Journal of Latin American Literary Criticism

Producción de espacio en la ciudad de Lima: la estética de los im/propio en la poesía de Domingo de Ramos.

literario $^{6}$. De Ramos se convierte en pasaporte a lo que de Certeau llama "marginal masivo".

Dividiendo Lima en dos zonas, la primera correspondiente a los distritos surgidos de barriadas y urbanizaciones populares, como San Martín de Porras, Comas, Carabayllo, Independencia, Villa María del Triunfo, San Juan de Miraflores, Carmen de la Legua, San Juan de Lurigancho y El Agustino; y la segunda que incluye a los distritos tradicionales y modernos, constituidos fundamentalmente por urbanización formal, podremos percibir la tendencia del cambio. En el censo de 1972 la primera zona albergaba al 24.4\% de la población de Lima y la segunda al 75.6\%. En 1981, según el censo, la primera aumentó a $32.5 \%$, mientras que la segunda disminuyó a $67.5 \%$. De acuerdo a las encuestas y trabajos realizados por el Instituto de Estudios Peruanos a fines de 1983, la primera zona alcanzó el $36.4 \%$ y la segunda el $63.6 \%$, lo cual significa un incremento sustancial, en 14 años, del 12\% para los distritos surgidos por invasión y urbanización popular y una disminución en igual proporción para los distritos constituidos por urbanización tradicional y legal. El desborde espacial y demográfico del considerable sector de población de bajo ingreso se perfila como el fenómeno más importante de la presente década. (Matos Mar 75-76)

Tener un miembro habitante de los pueblos jóvenes se lee como un medio de legitimación usado de forma recurrente. De tal modo, Kloaka representaría fielmente la realidad peruana. Por su parte, la resistencia de de Ramos a ser fijado como marginal contraviene el mito de lo popular, no porque su poesía sea desencantada, cruda, crítica (Zevallos, Vich), sino porque posee una confianza absoluta en la poesía como discurso y se asienta en un medio que le es impropio. Las publicaciones de De Ramos se suceden corroborando esta confianza: Poemas (1986), Arquitectura del espanto (1988), Pastor de perros (1993), Luna cerrada

\footnotetext{
${ }^{6}$ Mazzotti y Zevallos mencionan reiteradamente esta marginalidad en el campo que se debe, según ellos a varios motivos: mala fe de críticos y poetas que identificaban tendenciosamente la radicalidad política de los kloaka con una pertenencia o simpatía hacia Sendero Luminoso (Mazzotti 137, Zevallos 2002 29), y la descalificación e indiferencia por parte de la academia (Mazzotti 131, Zevallos 2002 14).
} 
(1995), Ósmosis (1996), Las cenizas de Altamira (1999), Erótika de Klase (2004), Pastor de perros (antología, 2006), Dorada Apocalipsis (2008), Demolido Fuego (2010), Cartas desde la azotea (2011) y Lima Pop (2012). Al interior de su proyecto, el poeta coloca el espacio del pueblo joven ${ }^{7}$ como materia poética, situando lo propio en lo impropio. Mi análisis no hace eco a la cuota que Santiváñez cubre; es decir, no lo estudio como voz o representante de los pueblos jóvenes, sino que indago en los recursos con los cuales la poesía de de Ramos cumple ese mandato de articular una experiencia migrante y también los sutiles pero contundentes mecanismos de rechazo de la asignación de marginalidad que viene desde muchos discursos adscrita a lo migrante. Como señala el epígrafe, De Ramos sobrepasa esa demanda externa y se inscribe y escribe por fuera de la marginalidad. En ese sentido, la migración es un tema que va más allá de la circunstancia de la época:

Porque nadie ha tomado en serio mi soledad

de animal acorralado por el fuego

mi obstinada permanencia en la vida

alfarero de las horas / del tiempo que pasa irremediablemente

sin pena y sin gloria en la esquina de mi barrio

con mis amigos y enemigos

con un sol y una luna persiguiéndome

como una maldita joroba

yo te digo

que esta noche me siento alejado de los hombres

diferente inexplicablemente

y tengo tantas ganas de estar solo

${ }^{7}$ El pueblo joven es el equivalente limeño a la villa miseria en Buenos Aires, la población en Chile, el rancho en Venezuela. Se trata barrios en los que se asentaron los migrantes, primero de forma muy precaria y que, con el pasar de los años y gracias a la organización colectiva, se convirtieron en áreas construidas con materiales nobles y abastecidas por los servicios básicos de agua, desagüe y luz eléctrica de los que carecían en un principio. 
CATEDral Tomada: Revista de crítica literaria latinoamericana / Journal of Latin American Literary Criticism

Producción de espacio en la ciudad de Lima: la estética de los im/propio en la poesía de Domingo de Ramos.

como un poste a medianoche

caminando en el silencio

de los arenales suaves como tapiz de grasa

pensativo

encerrado en mis propias imágenes

susurrando una canción

transpirando

bajo las sombras de los

edificios invertebrados

que se arquean como un laberinto de luz

("Escrito en soledad")

A esta reflexión filosófica sobre la soledad y la extrañeza que produce la vida social (esta noche me siento alejado de los hombres / diferente inexplicablemente) que es en sí misma un tropos poético tan antiguo como la idea misma de sociedad, cabe vérsele también como una imagen que contraviene las ideas de hacinamiento, proximidad y la solidaridad recurrentes en el imaginario sobre los pueblos jóvenes y los migrantes andinos. La solidaridad es vista como potencial de lo político por los científicos sociales de la época que trabajan la migración (Matos Mar, Degregori, Blondet, Lynch, Golte, Montoya). La poesía interrumpe el mandato de representar la solidaridad para aproximarse solitariamente a las imágenes del pueblo joven, los arenales suaves como tapiz de grasa, que no aparecen como escenografía urbana, sino que componen la singularidad de la voz poética: tengo tantas ganas de estar solo / como un poste a media noche. El sujeto transmuta en objetos de la calle y en espacio. Va componiendo el espacio del pueblo joven conjuntamente con un régimen de emoción que no es privativo ni ajeno a él, proponiendo un reacomodo estético en su poesía. Para Rancière, este tipo de proceso: “No se trata de la 'recepción' de las obras de arte. Se trata del tejido de experiencia sensible dentro del cual ellas se producen. Nos referimos a condiciones completamente materiales — lugares de 
representación y exposición, formas de circulación y reproducción-, pero también a modos de percepción y regímenes de emoción, categorías que las identifican, esquemas de pensamiento que las clasifican y las interpretan. ( $E l$ malestar en la estética 10$)$

Antes de la intervención de de Ramos en la poesía peruana, el arenal limeño de los pueblos jóvenes es impensable como espacio poético. Con él una posibilidad de experiencia migrante cuaja al interior de la poesía. Los edificios invertebrados adquieren materia en lo poético, son imaginables como lugares de representación dentro de la poesía. Mazzotti y César Ángeles señalan que la poesía de de Ramos es sincrética porque mezcla elementos rurales de la experiencia previa a Lima y las imágenes del pueblo joven con aquellas de la ciudad: "Es así como este proceso de sincretismo entre elementos específicos del mundo agrario y del suburbio y otras imágenes de corte grotesco otorga a Arquitectura del espanto su novedad en la poesía peruana de corte expresionista" (Mazzotti 142) ${ }^{8}$. "Es decir, se ocuparon [poetas dentro de los que está de Ramos] no sólo parcelas desérticas y abandonadas del territorio costero peruano, sino también su cultura dominante, su idioma, en una suerte de intercambio sincrético" (Ángeles 1). Los críticos detectan dos tipos de sincretismo en la poesía de de Ramos, el de Mazzotti que une lo rural con el pueblo joven y el de Ángeles que mezcla el pueblo joven con lo urbano, el desierto frente a la cultura y la lengua. Por otra parte, para Cornejo Polar el sincretismo es la mezcla siempre desbalanceada y conflictiva, aunque procure ser armónica, que realiza el mestizo a favor de la cultura occidental. En la formulación de Cornejo Polar mestizo y migrante son términos en gran medida excluyentes ("Condición migrante",

\footnotetext{
${ }^{8}$ Aquí la cita completa: "Sin embargo, insistamos en que el asco por las deformaciones de la vida de una sociedad tercermundista participa, después de todo, de una perspectiva popular. Esto se hace obvio si recordamos que muchas de las metáforas elaboradas dentro de este continuo lamento por un mundo carente de plenitud contienen elementos de ese mismo universo. Por ejemplo, en el poema 'Caída de un adolescente', uno de los mejores del conjunto, se dice que 'estaban [nuestros huesos] tan secos como tallos de maíz después de la cosecha" (Arquitectura 33), imagen que resultaría muy dudosa dentro del universo cultural de los poetas mucho más cultistas a los que ya me he referido en el Capítulo 3 de este libro [Eduardo Chirinos y Raúl Mendizábal]" (cursivas mías 141-142).
} 
Catedral Tomada: Revista de crítica literaria latinoamericana / Journal of Latin American Literary Criticism

Producción de espacio en la ciudad de Lima: la estética de los im/propio en la poesía de Domingo de Ramos.

Escribir en el aire) mientras que el mestizo usa el sincretismo y la transculturación para insertarse en la tradición occidental a la manera del Inca Garcilaso, el migrante, con una "movediza sintaxis" (“Condición” 108) trabaja lo fragmentario y parece ser que no quiere, o mejor, no puede integrarse. Aquí, la figura es Guamán Poma. Por otro lado, en todos estos críticos hay un entendimiento compartido de la radical oposición entre pueblo joven y ciudad “formal". Contrariamente, propongo que en la poesía de de Ramos el pueblo joven y la ciudad "formal" no aparecen como mundos excluyentes, sino como campos diferenciados de una misma experiencia social en la Lima de la época que se integran a un mismo discurrir poético a partir de una autoría que además tiene plena confianza en la poesía como medio de expresión e institución literaria. En ese sentido, el sincretismo como procedimiento que usa los contrarios y que Mazzotti y Ángeles explican escasamente resulta inadecuado para pensar una poesía que no trata estos elementos como radicalmente opuestos y que tampoco tiene un afán conciliatorio, más bien, estos son parte de una misma experiencia urbana como veremos en el poema "Banda nocturna".

Los usos del sincretismo a los que recurre la lectura crítica resaltan la importancia que tiene para esta el dato biográfico y la creencia profundamente ideologizada de que las provincias y los pueblos jóvenes son otro mundo, espacio de otros órdenes y con otras reglas, lenguaje foráneo en el que se es preciso ser originario si se quiere conocer y dar cuenta de él. Es sintomático encontrar en casi todos los artículos y reseñas sobre de Ramos la biografía como apoyo argumentativo de su poesía o de su performance como poeta:

- Con él sucedió — sucede- lo que con otros jóvenes escritores y artistas de extracción popular. Cuando evidencian su talento y capacidad de análisis, como es su caso, son recogidos por la crítica literaria como diamantes en medio del pantano. (cursivas mías, Ángeles 1)

- Domingo de Ramos, aprovecha su conocimiento desde adentro, de los sectores marginales y logra un buen libro que manifiesta en un nivel textual las contradicciones del universo extratextual. El autor de 
Arquitectura del espanto es hijo de migrantes y habita un barrio marginal limeño. (cursivas mías, Zevallos 1992, 167)

-Las publicaciones de Domingo de Ramos (Ica, 1960) representan la supervivencia en el desarrollo creativo de sujetos sociales marginales dentro del ámbito de la poesía “culta”. Y no se trata sólo de un criterio biografista. Aunque son sabidos los orígenes provincianos y suburbanos del poeta, así como su condición de hijo de migrantes andinos instalados como invasores en los arenales de San Juan de Miraflores en los años 60 (cursivas mías, Mazzotti 139)

- Es entonces cuando se apela al recuerdo del canto de la muchacha: una canción de la llamada música chicha, propia de los sujetos migrantes que viven en los arenales y barrios populares que bordean la capital, y de donde procede Domingo de Ramos (cursivas mías, de Lima 282)

Para Ángeles, una persona con talento y capacidad de análisis es recogida por la crítica de esa naturaleza pantanal que es el pueblo joven, el barrio marginal. De Ramos es también símbolo de supervivencia de la creatividad, la misma creatividad que los migrantes muestran, por ejemplo, para generar empleos y ocupaciones en una economía en crisis. De Ramos manifiesta su creatividad en la poesía, viene a ser a los ojos de la crítica una especie de folklorismo poético o rareza. La creatividad de los migrantes era una consigna difundida por los científicos sociales y empleada en todas las esferas, desde los medios masivos hasta la propaganda estatal. Matos Mar la explica así: “[el empresario informal] Es un hombre múltiple que día a día tiene que hacer frente a todos los problemas, haciendo gala de su ingenio y creatividad" (cursivas mías 56): "Esta presencia andina en el medio urbano constituye parte del nuevo rostro no sólo de la metrópoli limeña sino también del país en conjunto. La inorganicidad en que se expande, la espontaneidad, creatividad, y acomodo de lo serrano, se imponen como los signos dominantes de un intento masivo de los sectores populares por 
CATEDRAL Tomada: Revista de crítica literaria latinoamericana / Journal of Latin American Literary Criticism

Producción de espacio en la ciudad de Lima: la estética de los im/propio en la poesía de Domingo de Ramos.

conquistar un espacio social, más acorde con auténticos valores que hasta ahora no pudieron imprimir una tónica de identidad peruana” (cursivas mías 86).

La crítica incorpora a de Ramos desde la novedad y la diferencia haciendo eco del discurso de las ciencias sociales sobre los pueblos jóvenes, aunque reconozca la mitificación que este discurso produce. Si bien no se aprecia en de Ramos a una figura que conquista, se le ve dentro de estos círculos de críticos y poetas como portavoz del fenómeno social de la migración ${ }^{9}$, como el migrante que se apropia "selectivamente de los atributos que le son ajenos" (Cornejo, "Condición”, 101). El asombro hacia su poesía proviene de la percepción de que la literatura no es una ocupación comúnmente ejercida por los limeños de los pueblos jóvenes de quienes se espera que sean vendedores ambulantes, comerciantes, delincuentes. Más aún a los limeños de los pueblos jóvenes raramente se los piensa como limeños. De Ramos sabe que esos ambientes y objetos del pueblo joven que acompañan su experiencia en la ciudad son reconocidos y preciados por los críticos desde la diferencia. Conoce la comparativa excepcionalidad de su experiencia y el interés que ella suscita en el ambiente letrado limeño. Con ello no deslizo la idea de que estos referentes estén ahí como anzuelo, sino que hay una conciencia generalizada de la importancia de los pueblos jóvenes para la clase letrada, la intelectualidad progresista y los partidos de izquierda. Los libros de Matos Mar y Hernando de Soto son el lado más visible de ese interés, pero no el único. Los archivos sobre la época corroboran esa atención en tanto hay una serie de revistas de actualidad $-E l$

\footnotetext{
${ }^{9}$ Dos publicaciones canónicas sobre el tema de la migración trabajan la metáfora de la conquista: Conquistadores de un nuevo mundo. De invasores a ciudadanos de Carlos Iván Degregori, Cecilia Blondet y Nicolás Lynch y Los caballos de Troya de los invasores. Estrategias campesinas en la conquista de la gran Lima de Jürgen Golte y Norma Adams. Ambos libros hacen un primer deslinde respecto del discurso de las élites que perciben la migración como un fenómeno de deterioro social, de afeamiento de la ciudad y pérdida de las costumbres limeñas. Ambos imaginan la migración como un fenómeno mesiánico que equilibra el orden impuesto por la conquista y mantenido en la república. Los indios, campesinos, provincianos vendrían a reclamar y tomar una ciudad que les pertenece. Este relato aunque bienintencionado en tanto resalta agencia y movilidad social no deja de estar situado en la posición de las élites y equipara fenómenos distintos: "conquistar" derechos es fundamentalmente distinto que conquistar a un pueblo e instalar un sistema colonial.
} 
Zorro de Abajo, Quehacer, Caretas - que inciden en los esfuerzos de los partidos políticos, incluidos Sendero Luminoso y el MRTA, por capitalizar los pueblos jóvenes como espacios de militancia y a partir de este dato de Ramos también se lee como representativo en tanto militó en el Partido Comunista cuando adolescente. La militancia política en el pueblo joven refuerza doblemente el capital simbólico desde la marginalidad y desde la militancia como signo de radicalidad estética al interior de la poesía.

Por todo lo anterior, observo en su obra y en su performance pública un juego con la propiedad y la elaboración de una estética de lo im/propio. Propiedad entendida desde su relación con los sujetos y el medio, como medida para pensar lugares, posiciones, consumos y formas artísticas, aquella correlación entre sujetos y grupos que se asume como natural, citando a de Lima: "la música chicha propia de los sujetos migrantes" o a Cornejo Polar "atributos que le son ajenos". Lo propio y lo impropio refieren a una partición sensible, a una manera de estar en el mundo. Señalan también las circulaciones de los cuerpos. De Certau liga estos conceptos a un proceder típicamente asociado a la guerra en tanto predetermina el uso de estrategias y tácticas, simultáneamente, los coloca dentro de la producción como "maneras de hacer": "Llamo 'estrategia' al cálculo de relaciones de fuerzas que se vuelve posible a partir del momento en que un sujeto de voluntad y de poder es susceptible de aislarse de un 'ambiente'. La estrategia postula un lugar susceptible de circunscribirse como un lugar propio y luego servir de base a un manejo de sus relaciones con una exterioridad distinta" (XLIX-L). La estrategia es entonces posible solamente si hay visión panorámica, distancia. Para llevarse a cabo tiene que ocurrir una relación de pertenencia, se tiene que ser propietario para hacer sobre el terreno: "este es mi lugar y desde aquí hago". Mientras que la táctica es "un cálculo que no puede contar con un lugar propio, ni por tanto con una frontera que distinga al otro como una totalidad visible" (De Certeau L). La táctica y la impropiedad son territorios movedizos por eso de Certeau menciona que quien usa la táctica "Lo que gana no lo conserva. 
Necesita constantemente jugar con los acontecimientos para hacer de ellos 'ocasiones'." (L).

Antes que establecer un juego dicotómico entre lo propio y lo impropio, me interesa indagar en la oscilación y en las distintas relaciones con la propiedad que se pueden establecer en la poesía de de Ramos. Así, sobre todo al inicio de su carrera literaria, la poesía y la literatura son aquello ajeno al poeta, desde esa falta, el pueblo joven es lo propio. El tratamiento de este espacio urbano es estratégico mientras que su hacer dentro de la poesía resulta táctico, reescrito desde la diferencia y la curiosidad que supone su lectura, la cual se sitúa por fuera del pueblo joven. La biografía legitima ese escribir el pueblo joven sobre el que de Ramos ejerce un dominio. A diferencia de sus colegas limeños, él está autorizado por la propia crítica para hablar de $s u$ ambiente, el cual, a pesar de ser parte de la ciudad, se percibe como totalmente otro. No es una zona en la misma ciudad, es ante todo fenómeno social, algo que tiene que ser explicado por científicos antes de ser experimentado.

De Ramos subvierte este mandato de autenticidad en la medida en que propone un tránsito en la ciudad que sale del pueblo joven, no se queda en su lugar, de ahí que se le vea como sincrético. En el poema "Banda Nocturna" de la sección "Arquitectura del espanto" dice:

¡Oh el deslumbramiento del horror! Mejor será largarnos

de esta ciudad a la que nunca pertenecimos

y ya no tengo banderas ni multitudes

Estoy perdido

entre los edificios

entre las calles

y bocacalles

entre los cerros y basurales

deambulando con tu imagen impregnada en mi mente ("Banda nocturna”) 
La voz poética da cuenta de una circulación que ocurre de igual modo entre edificios, calles, bocacalles, cerros, basurales. No jerarquiza su deambular entre las áreas más "urbanas" de aquellas que se perciben como periféricas. En el mismo poema menciona esquinas, plazas, autopista, estera, mar, barrios, estas imágenes no entran solo en el repertorio del pueblo joven, sino que también son parte de la Lima oficial: "esta ciudad a la que nunca pertenecimos". Impera un mismo sentimiento de no-pertenencia respecto de la ciudad oficial y de la "informal" 10 . Ambas son parte de una experiencia urbana límite de desarraigo que abunda en el discurso poético moderno ${ }^{11}$. La propiedad del pueblo joven no basta como estrategia poética. A esta debe añadírsele una táctica de des-posesión para colocarlo en el mismo estatus de la ciudad "urbana", para que el migrante pueda salir y no permanecer en el falso oasis progresista de la pobreza. Ser un sujeto poético dentro de la contracultura implica tener una mirada crítica sobre su clase y desligarse de su medio. En las contraculturas anglosajonas (Roszak 51) y entre los Kloaka esto ocurre en contra de la burguesía urbana, en el caso de de Ramos lo que se escribe críticamente es el pueblo joven. En este sentido, antes que ver esta crítica como una forma de desmontar los discursos de las ciencias sociales para decir que el migrante ya no es garante de modernidad de acuerdo con la lectura de

\footnotetext{
${ }^{10}$ Dentro del debate de la migración, formal/informal fue una las dicotomías que atravesó todas las esferas y se hizo tan ubicua como desborde. Como explica Martos Mar, los migrantes ocuparon el espacio de lo informal por la zona en la que vivían, la calidad de sus viviendas, su condición de no limeños, sus prácticas comerciales que trastabillaban con lo ilegal (de Soto) y, pese a que muchos de estos fenómenos se trabajaron como una promesa económica, social, organizacional, continuaron teñidos por la falta. Por su parte, lo formal es una manera de hacer las cosas, una performance que denota puntualidad, seriedad, ceremonia, compostura, "modo de ejecutar con exactitud debida un acto público" (rae.com). De hecho, las élites provincianas de hacendados y las élites de empresarios en Lima transgredieron las leyes tanto o más que los migrantes, pero siempre dentro de términos formales, es decir, al interior de la corrupción del propio estado. Entonces, la informalidad que se le achacó al migrante hacía eco, más bien, a la falta de correspondencia entre ese sujeto particular y su transgresión. Sus transgresiones eran informales porque eran ajenas a ellos, no eran propias de su clase ni de su raza.

${ }^{11}$ La escritura de Benjamin sobre Baudelaire da cuenta de ello. Desde la figura del flâneur pasando por el aislamiento y el auto-extrañamiento del artista, Benjamin coloca estas fotografías urbanas como parte de la experiencia bohemia que se sitúa entre las bellas artes, lo masivo y la conspiración política.
} 
CATEDRAl Tomada: Revista de crítica literaria latinoamericana / Journal of Latin American Literary Criticism

Producción de espacio en la ciudad de Lima: la estética de los im/propio en la poesía de Domingo de Ramos.

Vich (Voces 219), pienso el gesto descreído de de Ramos como una operación poética propia de la contracultura. Con ello no pretendo despolitizar su poesía, sino colocarla en un pensamiento estético y político que confronte su discurso poético a la experiencia literaria contracultural local e internacional antes que confinarla a la producción de las ciencias sociales sobre los pueblos jóvenes.

Entonces, frente a una poesía que no ve estos espacios como promesas de modernidad alternativa y progresismo social, la escena subterránea aparece como posibilidad comunitaria ${ }^{12}$ :

Bajo la noche transparente

arden las veredas parpadean

los faros sobre los sucios

blue jeans de los jóvenes que se extravían entre esquinas

y parques claroscuros y negras casacas

entre brumas fosforescentes y blanquísimos cráneos

dientes rubios y dedos rubios escarchados por la yerba

Sus miradas brillan como hebillas de plata

llenan de tambores las plazas bañadas en aceite

y policías de felpa. (“Banda nocturna")

Aquí resuena la idea de Dick Hebdige sobre los “objetos humildes” como aquellos que desde su precariedad o desde su abyección son capaces de

\footnotetext{
${ }^{12}$ La escena subterránea es un fenómeno juvenil y urbano que concentra colectivos de poesía, música y artes plásticas conformado por jóvenes, colegiales, estudiantes universitarios, desempleados, etc. Las bandas de rock y punk son la punta de lanza de la escena. Aquello que la define y le da forma, que prefigura una "manera de andar" y una "manera de estar" afectiva y performática. Las canciones concentran en sus dos o tres minutos los afectos de la escena: ira, descontento, rebeldía, confusión. Estos se ven justificados y exaltados por las condiciones políticas y económicas del país. La violencia, la falta de oportunidades, la discriminación son objeto de crítica de esta cultura juvenil que cuenta con jóvenes de barrios bajos y obreros, así como con aquellos de sectores privilegiados. Lo subterráneo es una cultura juvenil que no se define solamente a partir de los rituales específicos de las subculturas: maneras de vestir, formas de asociación, consumo grupal de bienes culturales y otros como el alcohol y las drogas. A estas características propias de la subcultura se yuxtapone un proyecto contracultural que parte de la noprofesionalización, músicos y artistas amateurs, pero que también incluye a agentes con una mayor estabilidad dentro del campo cultural del momento.
} 
resignificar una experiencia ilegítima dentro de la sociedad y de la cultura: "such commodities are indeed open to a double inflection: to 'illegitimate' as well as 'legitimate' uses. These 'humble objects' can be magically appropriated; 'stolen' by subordinate groups and made to carry 'secret' meanings: meanings which express, in code, a form of resistance to the order which guarantees their continued subordination"13 (18). En de Ramos la pasta básica de cocaína ${ }^{14}$, la yerba, los blue jeans sucios cumplen esa función. Los objetos humildes de la subcultura se alternan con la creación del espacio urbano. De Ramos va componiendo una rutina juvenil en la que lo subte se despliega sin control sobre el espacio público, pero esa toma no es la de la fiesta, sino que está cercada por constantes alusiones al conflicto armado: "La ley es cruel me dicen los que sobrevivieron a esta / guerra inconclusa donde mi banda de leñadores se dedicó / a demoler las gordas columnas de la Justicia", "se aproximan // calle por calle / zona por zona cubiertas con los adolescentes / cuerpos de mi pandilla que ha saboreado la catástrofe // antes que el sol borre los resquicios y los escombros // a que fuimos sometidos".

La voz poética describe utópicamente una pandilla subte de leñadores que, a través de la violencia, demuele las convenciones. Se trata de una generación a la que le toca vivir una guerra ajena, a que fuimos sometidos. La doble acepción de banda como asociación criminal y conjunto musical juega con las posibilidades subculturales de la escena. Lo mismo ocurre con la imagen de la demolición que hace referencia al despliegue violento de la mancha, la banda, y también remite a la canción "Demoler” de Los Saicos ${ }^{15}$. Así, se reconocen en el poema los objetos,

\footnotetext{
${ }^{13}$ Hebdige lee el tubo de vaselina de Genet (The Thief's Journal) como un objeto paradigmático que delata su homosexualidad y es por ello abyecto para sus contemporáneos. Esta abyección se resignifica como un objeto de resistencia: "Genet finds consolation in the tube of vaseline. It becomes a symbol of his "triumph"' (3)

${ }^{14}$ En ese mismo poema la voz poética menciona: “y tú Sarita eres como un rockanrol en mi pecho / oliendo a pasta que consume mi banda pensando en ti".

${ }^{15}$ Esta agrupación es parte de la escena de la década de 1960 y, aunque desconectada de lo subte, no deja de ser una influencia y presencia importante. En un reportaje de febrero de 1985 los Leusemia y los Zcuela Crrada comentan: "En cambio los sesenta, sí eran buena nota [a diferencia del rock de los setenta], pero los primeros: Los Saicos — todos lanzan al unísono una
} 
CATEDRAL Tomada: Revista de crítica literaria latinoamericana / Journal of Latin American Literary Criticism

Producción de espacio en la ciudad de Lima: la estética de los im/propio en la poesía de Domingo de Ramos.

las coordenadas musicales y la actitud de la escena, el lenguaje obsceno y la marginalidad.

La veta de exploración de lo subte se hace más visible en la poesía de de Ramos tras la publicación de Pastor de perros. Ángeles cita una entrevista de 1993 en la que el poeta expresa que el personaje de su poesía: "más que un marginal es un subterráneo. Uno es marginal ante un grupo que le margina. Pero un subterráneo tiene una opción, ha decidido vivir en las cloacas" (3). Así, lo subte se convierte en una ocasión en términos de de Certeau, una táctica para afrontar la realidad, una decisión de pertenencia que, si bien se expresa negativamente también lo hace desde la voluntad y es independiente al rechazo externo. Esta mirada romántica de lo subterráneo como opción malditista está en la escena pero no es la única manera de caracterización de lo subte. Existen proyectos desde los cuales lo subte se asume como una crítica que si bien no se produce desde un área central de la cultura, tampoco lo hace desde la cloaca. Esta declaración, sin embargo, hace patente el peso de Kloaka para de Ramos aún después de terminado el colectivo en 1984. Lo subterráneo es en esta sentencia una manera alternativa de estar dentro de una ciudad marginalizante. Sin embargo, en "Banda nocturna" la utopía subte cede ante la realidad de la violencia: "Sobre las calles como una escuadra preparándome una celada // a plena luz del día con guardias de tránsito y helicópteros // de papel. Me detienen / me botan / me organizo y vago en // plazas y barrios demoliendo las gordas columnas de la Justicia // mientras mi banda se aleja // en tierra // en humo // en polvo // en sombra // en nada..." Pese a la aparición de la subcultura, la voz poética se encuentra nuevamente aislada. La banda subte desaparece fantasmagórica en este poema de De Ramos que transmite la insuficiencia de la comunidad de jóvenes frente a la represión policial. Estamos entonces ante una

exclamación aprobatoria- y ya un poco menos los Yorks y El Polen. Ellos empezaron bien la onda y después vinieron los otros a cagarla con su música en inglés". (Malca "La voz es el rock maldito") 
poesía que se piensa dentro de la escena pero que no la convierte en utopía. La usa como táctica, sin idealización, en una ciudad que no le es propia.

El poema se encuentra en una sección cuya metáfora principal es también la de todo el poemario: arquitectura del espanto. Esta arquitectura se remite a la ciudad de Lima y contiene por igual a los barrios tradicionales y a aquellos resultantes de la migración. La poesía de de Ramos dispersa imágenes de pobreza (casas destartaladas, covachas, esteras, arena) con aquellas otras, asociadas a la clase media o alta (edificios de vidrios, asfalto, mar, Oil Company). Junta términos disímiles para transmitir que esta situación es la misma en toda la ciudad. La arquitectura del espanto lo colma todo. Pero la arquitectura se asocia generalmente a las clases altas y medias, a las construcciones estatales. El pueblo joven es justamente lo contrario a la arquitectura, es la invasión, la improvisación, en el mejor de los casos, el ingenio y la creatividad. En las referencias de la época, estos barrios nunca son pensados desde lo arquitectónico. Todo lo contrario, lo que prima es un pensamiento sobre los arenales, el desierto, la naturaleza. Son ante todo paisaje. Ellio Martuccelli, arquitecto progresista, ex-Los Bestias $^{16}$, hace una elocuente descripción de lo que vendría a ser la oximorónica arquitectura de los pueblos jóvenes: "Pero de ninguna manera puede olvidarse que al lado del trabajo de estos y otros arquitectos continúa haciéndose una ciudad por obra de sus habitantes y que barrios enteros que aparecieron en la etapa anterior, en esta se estarían consolidando. Finalmente estas casas autoconstruidas se resuelven en su primera etapa en la más angustiosa necesidad: la vivienda de esteras, madera, cartón, que luego se traduce en ladrillo sin tarrajear y fierros que sobresalen anunciando próximas ampliaciones" (cursivas mías 207).

Las construcciones de los pueblos jóvenes son aquello que ocurre mientras en el resto de la ciudad se hace arquitectura. Estamos entonces ante una ciudad en

${ }^{16}$ Los Bestias (1984-1987) es un colectivo de estudiantes de arquitectura, cuya propuesta se basa en la idea de explotar el potencial político de las construcciones precarias de los inmigrantes andinos al interior de la disciplina y el ejercicio de la arquitectura en Lima durante aquella época. Entre los integrantes están Elio Martucelli, Alfredo Márquez, Enrique Wong, Alex Ángeles, entre otros. 
CATEDRAl Tomada: Revista de crítica literaria latinoamericana / Journal of Latin American Literary Criticism Producción de espacio en la ciudad de Lima: la estética de los im/propio en la poesía de Domingo de Ramos.

la que el $80 \%$ de sus habitantes prescinde de la arquitectura de acuerdo con la estadística de Matos Mar de las primeras páginas. Esta es una ciudad que se autoconstruye por fuera del reconocimiento institucional y disciplinario de la arquitectura. Mientras que la Lima de los arquitectos se edifica con concreto, la de los pueblos jóvenes, en cambio se hace de tierra, nuevamente, naturaleza: "Las casas inconclusas mezclan su color con el de la tierra: las metáforas de una ciudad para armar y desarmar no han podido ser más evidentes que en Lima: en este aire indefinido de la arquitectura popular limeña hay una extraña mezcla de abandono y esperanza" (cursivas mías Martucelli 200). Casi tan poético como de Ramos, el arquitecto describe un espacio popular de indefinición frente al arreglo racional que supone la arquitectura. Entonces, ¿qué implica proponer una arquitectura del espanto para la ciudad de Lima en su totalidad?

Al hacer de esta una arquitectura total, de Ramos contradice los discursos tradicionales y sugiere que incluso aquella área sin planificar es producto de una tendencia histórica. Es decir, hace eco a la idea de Lefebvre de que "el capitalismo es incapaz de hacer una planificación espacial” ("La producción del espacio" 220). Nuevamente se coloca en el terreno de lo impropio, en la medida que la arquitectura tampoco le pertenece a estos sectores sociales y es a través de la poesía que ese juego es posible. El cambio de escena que se produce es el de colocar en proximidad espacios, elementos y conceptos que no se leen ni se piensan juntos, que interrumpen la inercia generada desde los discursos de las ciencias sociales, que son a fin de cuentas, ideas reproducidas por la clase media letrada de izquierda o cercana a esta. La poesía le permite a de Ramos hacer arquitectura, pero no la arquitectura popular que menciona Martucelli ${ }^{17}$. Dos

\footnotetext{
${ }^{17}$ El grupo de música chicha (cumbia peruana) Los Shapis hace uso de la figura del arquitecto pero desde las antípodas del discurso de de Ramos y, más bien, dentro del horizonte progresista de los estudios sobre migración. En su canción "Somos estudiantes" dicen: "Somos estudiantes / Somos el Perú / Somos profesores para nuestra niñez / Médicos seremos para la orfandad / Somos ingenieros para nuestro país / Arquitectos somos de nuestro destino". Se trata entonces de dos usos de la arquitectura muy distintos que, si bien ambos salen de productores migrantes, están en clara dependencia de sus medios y tradiciones. En el caso de música popular, la arquitectura y la educación superior son medios de legitimación y entrada a lo nacional.
} 
productos principales de la alta cultura, poesía y arquitectura, se convierten en medio y objeto de su táctica impropia.

Propongo ver a de Ramos como el arquitecto, el productor de este espacio poético y urbano. A diferencia del discurso de Martuccelli en el del poeta no hay jerarquías entre las arenas y los terrales de los pueblos jóvenes y la ciudad de cemento: todo compone una arquitectura del espanto. No se trata de una arquitectura que racionaliza, acomoda, posibilita la circulación y la producción. Todo lo contrario es una arquitectura que entrampa, pierde, confunde. Ni el pueblo joven es el espacio utópico de lo económicamente emergente que bienintencionadamente pintaron, ni la Lima de la clase media es el lugar de la formalidad. Para Lefebvre el problema de la producción capitalista había pasado a ser el de una producción del espacio antes que una producción en el espacio. Es decir, lo que se produce es el espacio social en su conjunto, no son solo objetos o bienes. Desde su perspectiva espacios dominantes, la Lima formal, producen espacios dominados, los pueblos jóvenes. Esta interpretación es compartida por los científicos sociales limeños que atribuyen la migración como fenómeno masivo a la falta de empleo, la violencia, la pobreza de las áreas rurales. Pero mientras que en Lefebvre el espacio dominante ostenta su pragmaticidad, su eficacia para crear fantasías de orden, de consumo de bienes y consumo espacial, el espacio que de Ramos produce es el de una arquitectura en la que si bien la relación dominante y dominado permanece no sin ser complejizada, toda performance de solvencia arquitectónica racionalista se hace imposible.

Lima la horrible (1964) de Sebastián Salazar Bondy también retrata una ciudad colapsada y podría pensarse que Arquitectura del espanto toma de esta tradición. Sin embargo, a diferencia de Bondy que ve en la modernidad y lo nuevo la promesa del progreso y el compromiso de toda intervención intelectual, de Ramos muy de acuerdo con su época, se solaza en soluciones pasajeras: el placer sexual, la droga. No obstante, su labor literaria traza en la poesía y el lenguaje una salida duradera. Aunque esta poesía produce un espacio desolador, con personajes acabados por la miseria y la guerra, es una poesía que confía en el poder 
CATEDRAL Tomada: Revista de crítica literaria latinoamericana / Journal of Latin American Literary Criticism Producción de espacio en la ciudad de Lima: la estética de los im/propio en la poesía de Domingo de Ramos.

expresivo del lenguaje. En el poema "No tengo nada que decir" la voz poética toma la forma enfática del lamento:

No tengo historia / he sido despojado de afecto los constantes ayunos los golpes y la insaciable sed el desentierro hasta siento desarraigo de este cuerpo inefable / Es posible que yo haya sido hecho a la medida de mis semejantes como tantos otros ciertamente nebulosos granulosos seco como un pallar tallado en piedra Mi alma ha sido arrojada al mar y no sé cómo escapar de su corriente de sus largas garras del gobierno de estos seres que me siguen tendiéndome cercos para no verte ahora ni nunca / Todo esto me causa repulsa tus obreros vestidos de overol verde de la Oil Company que compran cervezas y se emborrachan con prostitutas y gerentes en los burdeles solitarios donde trabajaste montando sobre cuerpos sudorosos aceitosos con el tufo asfixiante de la humedad de los cuartos resquebrajados por el sol o sobre las playas desdibujadas por el aliento de las viejas focas que cachan con los marineros alucinados y doblados por su intima tristeza de animales moribundos con un rostro de reliquia tal vez mirando las doradas aguas que se descorren como un tiempo atrás y ven el semblante de una mujer resplandeciendo como un doblón antiguo

"Todo lamento es siempre lamento por el lenguaje, así como toda alabanza es sobre todo loa del nombre. Estos son los extremos que definen el ámbito y la vigencia de la lengua humana, su referirse a las cosas. Donde la naturaleza se siente traicionada por el significado, allí comienza la lamentación; donde el nombre dice perfectamente la cosa, el lenguaje culmina en el canto de alabanza, en la santificación del nombre" (39) dice Agamben en La Comunidad que viene. La poesía de de Ramos está en el extremo de lo indecible de ese pathos ontoteológico. Es una poesía que repite incansablemente el lamento y con ello la 
imposibilidad de decir, la incapacidad del significado de referirse a la cosa. Agamben nos dice que este gesto sin embargo, se funda en su contrario, la posibilidad de santificar el nombre para alimentar el propio poder referencial. Por su parte, la de Domingo de Ramos es una poesía que se hace desde la imposibilidad de nombrar y en la repetición de esta imposibilidad se halla una crítica de la impropiedad del lenguaje. El pseudónimo de Domingo de Ramos no es aquel que está "a gusto entre nombre y apodo" (Agamben La comunidad, 40), al contrario, es el pseudónimo incómodo, irónico y amargo que habla desde la incapacidad de redención, desde la impotencia de no poder santificar el nombre y, desde aquí, todo intento comunitario es inviable.

El conflicto armado refuerza esta imposibilidad y añade su cuota de muerte y sinsentido a la realidad y al lenguaje. En el poema "Su cuerpo es una isla de escombros" que es parte de la última sección del libro "NN", aparece la figura del cronista Guamán Poma de Ayala para fijar una continuidad sobre la desigualdad y la injusticia entre la colonia y la década de 1980:

Vuela

1500 ó 1600 Huamán Poma de Ayala

nos cuenta de sus amoríos

de sus vísceras recientemente disecadas para nuestro museo

en nuestros textos de historia

Huamán Poma con su antigua indumentaria

representa una casta de artículos para el turismo

y las razas sociales y económicas en la tierra que

ahora pisa y sus dibujos y la crónica

se pueden leer en los noticieros

y también lo anuncian por

la Coca Cola en un periódico de izquierda

Huamán Poma habla quechua

vende diarios 
CATEDRAL Tomada: Revista de crítica literaria latinoamericana / Journal of Latin American Literary Criticism Producción de espacio en la ciudad de Lima: la estética de los im/propio en la poesía de Domingo de Ramos.

\author{
y papas \\ trabaja en una construcción como la \\ de Macchu Picchu
}

\begin{abstract}
No coincido con la lectura de Vitelia Cisneros que encuentra en este poema, pese a que no hay referencias directas, una conexión con el mito del Inkarri. Veo, más bien, la incorporación de la figura desmembrada de Huamán Poma como la imposibilidad de registrar la historia de ese presente del conflicto armado. En este poema de Ramos explora el personaje histórico a partir de referentes contemporáneos que hablan de una fetichización de lo indígena para el mercado y la cultura (turismo, noticieros, Coca Cola, periódico de izquierda, textos de historia, museos). Pero Guamán Poma también es migrante y hace cosas “propias” de su clase. Es ambulante, constructor, subversivo, borracho, bailarín de chicha y, por ello, termina asesinado:
\end{abstract}

El Sol preguntó averiguó su paradero

se enteró que lo apresaron por las cercanías del palacio

ató sus cadenas en las columnas

iluminó sus bóvedas

oscuras donde un pulpo estrangulaba una presa y lo devoró

pero Huamán Poma fue torturado vaciado al mar

depositado en una fosa y finalmente

su cuerpo es una isla en escombros.

Aquí se hace referencia a la isla El frontón en la que se ubicaba la cárcel de presos políticos asesinados extrajudicialmente en la masacre de las cárceles de 1986. En versos anteriores se menciona: "un cortamontes de donde pendían / las cabezas de los que murieron en 1986 aproximadamente / cuando cayó el imperio por el virrey de Lurigancho". Lurigancho es uno de los penales abatidos durante 
este suceso. Entonces, esta referencia sugiere que el estereotipo del migrante es blanco de sospecha. Como lo eran los leñadores de "Banda nocturna", los migrantes son sospechosos para la policía, susceptibles de ser detenidos, encarcelados y asesinados extrajudicialmente. La superposición de la figura de Guamán Poma refuerza el lamento, la impropiedad del lenguaje y la imposibilidad de toda crónica o denuncia. No se trata solamente como escribe Agamben de la “desconfianza pequeño-burguesa frente al lenguaje", sino de un recelo que se cruza con lo colonial, siguiendo a Silvia Rivera Cusicanqui:

Hay en el colonialismo una función muy peculiar para las palabras: las palabras no designan, sino encubren, y esto es particularmente evidente en la fase republicana, cuando se tuvo que adoptar ideologías igualitarias y al mismo tiempo escamotear los derechos ciudadanos a una mayoría de la población. De este modo, las palabras se convirtieron en un registro ficcional, plagado de eufemismos que velan la realidad en lugar de designarla. Los discursos públicos se convirtieron en formas de no decir. $\mathrm{Y}$ este universo de significados y nociones no-dichas, de creencias en la jerarquía racial y en la desigualdad inherente de los seres humanos, va incubándose en el sentido común, y estalla de vez en cuando, de modo catártico e irracional (1-2).

En otro nivel, la referencia a Guamán Poma liga esta Arquitectura del espanto a una genealogía que no solo implica a Lima, sino a todo el país. De Ramos usa estratégicamente un autor de gran carga cultural y hegemonía en el campo, un gesto que evade la marginalidad en la que se lo quiere encasillar. Y es que esta es ante todo una categoría de la crítica. Desde lo urbano, de Ramos descarta la marginalidad con una estética de lo im-propio que combina lugares y produce un espacio que, aunque marcado por contradicciones, es parte de una misma experiencia social. Ello con un discurso poético que desconfía del lenguaje al mismo tiempo que se apropia de la poesía. La de de Ramos tampoco es una marginalidad entendida como lo accesorio, secundario o de poca importancia. A través de una utilización de temáticas y autores centrales a la historia de la poesía y de la literatura nacional de Ramos apunta la centralidad de su elaboración 
CATEDRAL Tomada: Revista de crítica literaria latinoamericana / Journal of Latin American Literary Criticism

Producción de espacio en la ciudad de Lima: la estética de los im/propio en la poesía de Domingo de Ramos.

poética y de su autoría, opuesta completamente a los valores de lo solidario y lo espontáneo asociados a los pueblos jóvenes. Del mismo modo, tampoco procura una circulación marginal. El blog del poeta funciona antes que como diario personal o bitácora como una página electrónica dedicada a la crítica sobre su obra, a los eventos en los que participa y a sus libros. Además de sus publicaciones en solitario, sus antologías y congresos figura en su biografía una memoria breve sobre sus viajes: "Su último viaje fue a fines del 2008, iniciando una gira internacional, en donde asistió al Encuentro Internacional de Escritores en México Monterrey y luego a la ciudad de Boston, leyendo en las universidades de Tufts, Harvard, Nueva York, DePaul University de Chicago, Temple de Filadelfia y finalmente en el Festival Latinale de Berlín-Alemania organizado por el Instituto Cervantes de esa ciudad y de Bremen".

Esta lista funciona como una afirmación de la centralidad de su poesía y dibuja un mapa de participaciones en países con industrias y tradiciones culturales importantes. No es una muestra de cosmopolitismo, pero es sin suda una negación de marginalidad o al menos una convivencia de lo marginal con lo central e institucional. Dentro de los ex-Kloaka que continúan escribiendo y publicando poesía, de Ramos no tienta - tampoco Dalmacia Ruiz Rosas-, una carrera académica en Estados Unidos. Por otro lado, quienes lo hacen -Mariella Dreyfus, Róger Santiváñez y José Antonio Mazzotti- no son leídos desde la marginalidad del grupo. Es decir, Kloaka pesa en sus carreras literarias como una extravagancia juvenil: "Todo lo consumíamos aceleradamente, como si la vida fuese a terminarse al día siguiente, con un sentido de urgencia, un vitalismo que también tenía sus 'caídas hondas de arquitecto', como diría Vallejo, porque era muy difícil ser joven y estar contento en Lima en ese momento" (Dreyfus en Yrigoyen y Torres Rotondo 224). De Ramos es entonces, el único que debe sacudirse de esa asignación de marginalidad por provenir de los pueblos jóvenes. Para ello desarrolla estrategias dentro y fuera de lo poético.

El discurso poético de de Ramos va trazando zigzagueante, aunque no por ello inconstante, una estética del lenguaje de lo im-propio, aquel que no puede 
nombrar la propiedad y la pertenencia al mundo de las cosas, ese lenguaje que es incapaz de reproducir su poder referencial. Este es un gesto que sus libros y su carrera literaria reactualizan, instalando una perseverancia en el descreimiento en el ámbito creyente de la poesía. Esta vieja operación se lleva a cabo a través de un lamento desjerarquizador de la distribución entre espacios, sujetos y ocupaciones en la ciudad. Incorporando el pueblo joven al resto del territorio urbano el poeta no junta dos lugares disímiles, sino que da cuenta de la naturaleza amalgamada y confusa de un mismo lugar. Se ase de un campo que le es impropio, ajeno y en el que es recibido como rareza. Satisface una demanda por lo popular al mismo tiempo que cuestiona su imagen idealizada.

Partir de Domingo de Ramos y del concepto de marginalidad como una demanda desde fuera y una táctica dentro de la cultura permite justamente escudriñar los conceptos asociados a la estética y la aparición de la escena subterránea como fenómeno social, desde su aspecto subcultural, y como manifestación contracultural en el campo cultural del momento. Los grados de cercanía y reconocimiento que los miembros de la escena guardan con estos conceptos expresan la duración de la misma, sus reacomodos y sus necesidades históricas. La estética de lo im/propio de de Ramos elabora desde múltiples niveles las relaciones entre el lenguaje, los referentes, las prácticas culturales y los espacios sociales. Introduce visiones y emociones ajenas a la poesía redistribuyendo lo sensible y apreciable, haciendo que otro tipo de voz poética, de escenario y de sujeto se conviertan en materia de lo poético. Y, así debe entenderse su apuesta final por la poesía y el lenguaje en abandono de la marginalidad y lo subte, como parte de esa afirmación estética dentro de la poesía. 
CATEDRAL Tomada: Revista de crítica literaria latinoamericana / Journal of Latin American Literary Criticism Producción de espacio en la ciudad de Lima: la estética de los im/propio en la poesía de Domingo de Ramos.

\section{Bibliografía}

Agamben, Giorgio. La comunidad que viene. Valencia: Pre-Textos, 1996.

Ángeles, César. "La poesía de Domingo de Ramos y Pastor de perros".

Ciberayllu. Missouri: 2001

$<$ http://www.andes.missouri.edu/andes/Especiales/CALRamos/CAL_Ra

mos 1.html>

Benjamin, Walter. The Writer of Modern Life. Essays on Charles Baudelaire. Cambridge, Massachusetts, and London: Hardvard UP., 2006.

Cisneros, Vitelia. “Cuerpo y nación a través del poema 'Su cuerpo es una isla en escombros' de Domingo de Ramos”. Romance Quarterly (2009), 56:4, 293-305.

Cornejo Polar, Antonio. Escribir en el aire. Ensayo sobre la heterogeneidad sociocultural en las literaturas andinas. Lima, Berkeley: CELACP, Latinoamericana, 2003.

. "Condición migrante e intertextualidad multicultural. El caso Arguedas".

Revista de Crítica Literatura Latinoamericana, Año 21, No. 42 (1995), pp. 101-109.

de Certeau, Michel. La invención de lo cotidiano. Las artes de hacer. México: Universidad Iberoamericana, 2000.

de Lima, Paolo. "Violencia y 'Otredad' en el Perú de los 80: de la globalización a la 'Kloaka'". Revista de Crítica Literaria Latinoamericana, Año 29, No. 58, Poesía y Globalización (2003), pp. 275-301.

de Ramos, Domingo. Banda nocturna: antología 1987-2012. Lima, Intermezzo Tropical, 2012.

. Cartas desde la azotea. Lima: Mesa Redonda, 2011.

. Demolido fuego. Arequipa: Cascahuesos, 2010.

. Dorada apokalipsis. Lima: Intermezzo Tropical, 2008.

. Pastor de perros (Antología). 2006.

. Erótika de clase. Lima: El Virrey, 2004. 
. Las cenizas de Altamira. Lima: Domingo de Ramos, 1999.

. Ósmosis. Lima: Ed. Copé, Petroperú, 1996.

. Luna Cerrada. Lima: Asaltoalcielo, 1995.

. Pastor de perros. Lima: Asaltoalcielo, Colmillo Blanco, 1993.

. Arquitectura del espanto. Lima: Asaltoalcielo, 1988.

. Dorada apokalipsis. Blog. <http://domingo-de-

ramos.blogspot.com/2009/09/dorada-apocalipsis.html>

de Soto, Hernando. El otro Sendero. La revolución informal. Lima: Barranco, 1986.

Dreyfus, Mariella. Memorias de Electra. Lima: Orellana \& Orellana, 1984.

Hebdige, Dick. Subculture. The Meaning of Style. London, New York: Routledge, 2002.

Lefebvre, Henri. "La producción del espacio". Papers. Revista de Sociología. Año 1974, No. 3, pp. 219-229.

Lynch, Nicolás. Una tragedia sin héroes. La derrota de los partidos y el origen de los independiente. Perú 1980-1992. Lima: Universidad Nacional Mayor de San Marcos, 1999.

Malca, Oscar. "La voz es el rock maldito. Crónica de los nuevos rockanroleros limeños". VSD. La República, 8 de febrero 1985.

Martuccelli, Elio. Arquitectura para una ciudad fragmentada. Ideas proyectos y edificios en la Lima del siglo XX. Lima: Universidad Ricardo Palma, 2000.

Matos Mar, José. Desborde popular y crisis de estado. Lima: Instituto de Estudios Peruanos, 1984.

Mazzotti, José Antonio. Poemas no recogidos en libro. Lima: Federación Universitaria de San Marcos, 1981.

. Poéticas del flujo, migración y violencia verbales en el Perú de los 80. Lima: Fondo Editorial del Congreso del Perú, 2002.

Montoya, Rodrigo. Cultura quechua hoy. Lima: Hueso Húmero, 1987.

Oviedo, José Miguel. Estos 13. Lima: Mosca Azul, 1973. 
Catedral Tomada: Revista de crítica literaria latinoamericana / Journal of Latin American Literary Criticism Producción de espacio en la ciudad de Lima: la estética de los im/propio en la poesía de Domingo de Ramos.

Podestá, Cecilia. En la periferia del diálogo. Entrevista a Domingo de Ramos. https://lamula.pe/2012/06/09/en-la-periferia-del-dialogo-entrevista-adomingo-de-ramos/ceciliapodesta/

Rancière, Jacques. El malestar en la estética. Buenos Aires, Capital Intelectual, 2011.

Rivera Cusicanqui, Silvia. "La universalidad de lo ch'ixi: miradas de Waman Puma". e-misférica, No. 7.1., 2010, pp. 1-16. http://hemisphericinstitute.org/hemi/en/e-misferica-71/rivera-cusicanqui

Roszak. The Making of Counter Culture. New York: Anchor Books,1969.

Salazar Bondy, Sebastián. Lima la horrible. México D.F.: Era, 1964.

Santiváñez, Roger. Antes de la muerte. Lima: Cuadernos de hipocampo, 1979. . Homenaje para iniciados. Lima: Reyes en el Caos, 1984.

Torres Rotondo, Carlos y José Carlos Yrigoyen. Poesía en rock. Una historia oral. Perú 1966-1991. Lima: Ediciones Altazor, 2010.

Velarde, José Alberto. La última cena. Poesía peruana actual. Lima: Asalto al Cielo, Naylamp, 1987.

Vich, Víctor. Voces más allá de lo simbólico. Ensayos sobre poesía peruana. Lima: Fondo de Cultura Económica de Perú, 2013.

Zevallos, Ulises. MK (1982-1984): cultura juvenil urbana de la postmodernidad periférica. Estudio introductiorio, antología y recopilación de documentos. Lima: Ojo de Agua, 2002.

. "Domingo de Ramos, Arquitectura del espanto. Lima, Asaltoalcielo Editores, 1988." Revista de Crítica Literaria Latinoamericana, Año 18, No. 35 (1992), pp. 166-167. 